\title{
MAXIMIZING NITROGEN AND WATER USE \\ EFFICIENCY UNDER DROUGHT CONDITIONS IN EGYPT
}

\author{
Mahmoud M. Elbordiny* and Khaled F. El-Bagoury**
}

ABSTRACT

Nitrogen loss by leaching is considered a major problem, particularly under higher $N$ requirement. Consequently, a study was conducted to determine the effect of decreasing rates of inorganic nitrogen and irrigation scheduling on distribution of both chemically available soil nitrogen and soil moisture content as well as grains yield of corn. To test this assumption, corn (Zea mays, variety single hybrid 10) was selected and four nitrogen treatments were applied at EL-Khatatba area, ElMonofia, Egypt: (a) Control, $100 \mathrm{~kg} \mathrm{~N} /$ fed as $\left(\mathrm{NH}_{4} \mathrm{NO}_{3}, 33 \% \mathrm{~N}\right),(b) 80$ $\mathrm{kg} \mathrm{N} / \mathrm{fed}+$ compost, (c) $70 \mathrm{~kg} \mathrm{~N} / \mathrm{fed}+$ compost and (d) $60 \mathrm{~kg} \mathrm{~N} / \mathrm{fed}+$ compost. The compost added to the soil at the rate of $2 \%$. As well as three drip irrigation scheduling were applied with fixed total applied water amounts: (1) daily irrigation, (2) three days intervals (every second day) and (3) two days intervals (every third days) with 4L/h emitters. Chemically available nitrogen and soil water content in the intervals soil depths (0-30, 30-60 and 60-90 cm) as well as nitrogen content in plants and grains yield were determined. The results indicate that the root zone was contain higher moisture with application of daily and two days intervals irrigation treatments compared to three days intervals. Application of three days intervals increased water content with the increasing soil depth especially with increasing time of experiment. High amounts of nitrogen were existing in the upper layer $(0-30 \mathrm{~cm})$ of the soil and it decreased gradually by going deeper to reach (at 60-90 cm). The total cumulative amounts of nitrogen from 0-60-cm depth were sufficient level with different treatments. The available nitrogen was 290, 283, 243 and $202 \mathrm{mg} / \mathrm{Kg}$ soil with application of $100 \mathrm{~kg} \mathrm{~N} / \mathrm{fed},(80 \mathrm{~kg} \mathrm{~N} / \mathrm{fed}+$ compost), (70 kg N/fed +compost) and (60 kg N/fed +compost) at flowering stage, respectively.

Associate Prof. of Soil, Fac. of Agric., Ain Shams Univ.

** Assistant Prof. of Agric. Eng., Fac. of Agric., Ain Shams Univ 
Chemically available $N$ levels in the soil were increasing and moving downward when soil irrigated three times weekly. Application of $80 \mathrm{Kg} \mathrm{N}$ /fed combined with compost and two days intervals or daily irrigation increased markedly nitrogen content in -corn plant and grain yield of corn plants compared with other treatments with respect of irrigation scheduling.

Key words: Nitrogen movement- irrigation scheduling-compost- corn grain yield.

\section{INTRODUCTION}

lobally, fertilizer nitrogen applications are approximately 80 Tmillion tones, with half being applied in developing countries (FAO, 1990). It has been estimated that by the year 2025 the consumption of nitrogen fertilizer will increase 60 to $90 \%$, with twothirds of this being applied in the developing world (Galloway et al., 1995). This trend in fertilizer use is mostly driven by the need of developing countries to keep food supply up with population growth.

Efficient water use under irrigation systems is becoming increasingly important especially in arid and semi-arid regions with limited water resources. In agricultural practice, the sufficient and balanced application of irrigation water and nutrients are important methodology to obtain maximum yield per unit area. Sanchez (2000) demonstrated that lettuce yield increased in response to water and nitrogen. Steele et al., (2000) demonstrated that irrigation water management can be used to optimize corn yield, which can decrease the amount of $\mathrm{NO}_{3}-\mathrm{N}$ leached by improving $\mathrm{N}$ uptake by corn. Nitrogen management practices can be developed to minimize adverse impacts on surface and subsurface water, while maintaining sufficient yields. On the other hand, excessive application of irrigation water and nutrients result in some serious problems (Türkmen et al., 2004). The increase in soil moisture that results from the initiation of irrigation dissolves excess $\mathrm{NO}_{3}-\mathrm{N}$ present in the soil profile from dryland agriculture and makes it more susceptible to leaching (Albus and Knighton, 1998). The increase in mineralization rates has been shown to directly affect nutrient leaching (Doran, 1980). Minimizing nutrient leaching can be achieved by matching water and fertilizer application rates to plant uptake rates. Soil water potential and 
water content in the vicinity of active roots generally controls the rate of water and nutrient uptake by plants. Drip irrigation is an acknowledged technique for achieving high efficiencies in water use of crops by wetting only a limited part of the root zone (Bresler et al., 1982). Several authors have shown that efficiencies might be improved without affecting crop yield by decreasing the amount of water leached from the root zone through more optimal drip irrigation management (Darusman et al., 1997). Frequency and emitter discharge determine the variation in soil water potential, and consequently, root distribution and plant water uptake patterns (Coelho and Or, 1999). Drip irrigation systems allow the delivery of $\mathrm{N}$ to the area of maximum crop uptake, and match the rate of application to the plants' requirements. Drip irrigation systems generally consist of emitters that have discharge rates varying from 2 to $8 \mathrm{~L} / \mathrm{h}$. In semiarid summer climates crop water use is generally 6 to $8 \mathrm{~mm} / \mathrm{d}$ (Coelho and Or, 1996), and water is supplied two or three times a week. Therefore the duration of water application is much shorter than the time over which plants take up water. Even if the water is supplied on a daily basis, a water application rate of $2 \mathrm{~L} / \mathrm{h}$ delivers the consumptive needs of plants in a small fraction of the time over which plants photosynthesize and transpire. This means that even for water applications exactly equal to plant water needs, part of the water may not be used by the plant and would most likely drain below the root zone. Lowering emitter discharge rates to as close as possible to plant water uptake rates may reduce these percolation losses.

Organic manures, such as cow dung; poultry manure and crop residues can be used as an alternative for the inorganic fertilizers. Nutrients contained in organic manures are released more slowly and are stored for a longer time in the soil, thereby ensuring a long residual effect (Sharma and Mittra, 1991 and Elbordiny, 1996). Improvement of environmental conditions and public health as well as the need to reduce costs of fertilizing crops are also important reasons for advocating increased use of organic materials (Seifritz, 1982). The soil fertility status is improved by activating the soil microbial biomass and also improve the water holding capacity of the soil; improve the soil structure and the soil aeration (Belay et al., 2001). Application of organic manures plays a 
direct role in plant growth as a source of all necessary macro and micronutrients in available forms during mineralization, thereby improving both the physical and the biological properties of the soil. Also, organic manures decompose to give humus which plays an important role in the chemical behaviour of several metals in soils through the falvic and humic acid contents, which have the ability to retain the metals in complex and chelate forms (Abou El-Magd et al., 2006). The objective of this study was to effects of application of compost with inorganic fertilizer and scheduling drip irrigation on distribution of chemically available nitrogen and water in soil profile and dry grain yields of corn.

\section{MATERIALS AND METHODS}

An experiment was conducted in EL-Khatatba area, El-Monofia, Egypt $\left(31^{\circ} 15^{-} 25^{--} \mathrm{N}\right.$ latitude and $30^{\circ} 04^{-} 14^{--} \mathrm{E}$ longitude). Corn (Zea mays, variety single hybrid 10) were chosen to evaluate the effect of $\mathrm{N}$ fertilizer rate with or without compost and irrigation frequency on soil nitrogen following fertilizer-N uptake efficiency and grain yield of corn. Soil texture is silt loam (sand 39\%, silt 29\%, and clay 32\%) with a bulk density of $1.42 \mathrm{~g} \mathrm{~cm}^{-3}$, with a $\mathrm{pH}$ of 7.8 (1:2.5 in water), total soluble salts in soil paste of $0.47 \mathrm{dS} / \mathrm{m}$, organic matter of $0.22 \%, \mathrm{CaCO}_{3}$ content of $3.61 \%$ and $20.9 \mathrm{mg} / \mathrm{kg}$ available $\mathrm{N}$. In a field experiment, corn was planted in May 2008. A split-plot arrangement of the experimental treatments was used with irrigation treatments as main plots and $\mathrm{N}$ fertilization applications as subplots with three replicates (figure, 1). Each plot was $(15$ by $20 \mathrm{~m}$ ) and included four plant rows (furrow every 0.75 meter). Only the two central rows were used for sampling. Three drip irrigation intervals: (1) daily irrigation with, (2) three days intervals (every third days) (commonly applied in the region) and (3) two days intervals (every second days). Emitter spacing was every $0.3 \mathrm{~m}$ for the 4 $\mathrm{L} / \mathrm{h}$ discharge at pressure 1 bar. Total water applied for irrigation was similar for all treatments $579 \mathrm{~mm}$ in the season. The irrigation applied (irrigation time two hours) at through the drip system was scheduled using combined pan evaporation and growth stage based crop coefficient, according to recommended irrigation practice for the region table (1). 


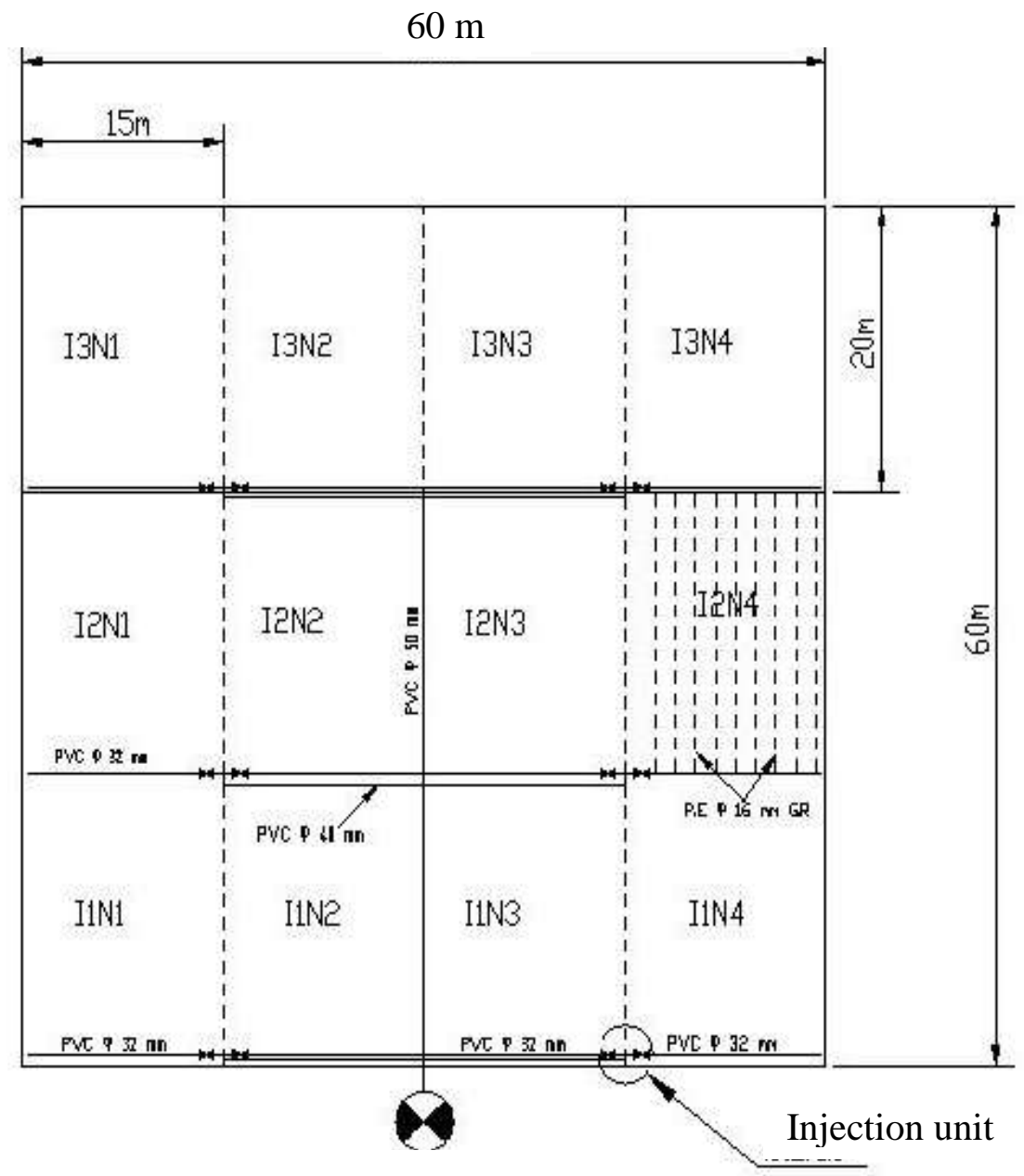

\begin{tabular}{|l|l|}
\hline I1 = daily interval & $\mathrm{N} 1=100 \mathrm{~kg}$ (nitrogen) \\
I2 = Two days intervals & $\mathrm{N} 2=80 \mathrm{~kg}$ (nitrogen) \\
$\mathrm{N} 3=70 \mathrm{~kg}$ (nitrogen) \\
I3 = Three days intervals & $\mathrm{N} 4=60 \mathrm{~kg}$ (nitrogen) \\
\hline
\end{tabular}

Fig. 1. Layout irrigation system and experiment treatments. 
Whereas, the nitrogen and compost treatments were included: (a) Control (100 kg N/ fed was applied with out compost as recommended by Ministry of Agriculture) as $\left(\mathrm{NH}_{4} \mathrm{NO}_{3}, 33 \% \mathrm{~N}\right)$, (b) 80 unit $\mathrm{N} / \mathrm{fed}+$ compost, (c) 70 unit $\mathrm{N} / \mathrm{fed}+$ compost and (d) 60 unit $\mathrm{N} / \mathrm{fed}+$ compost. The compost added to the soil at the rate of $2 \%$ (20 ton/ fed by weight,). Some characteristics of the compost used are shown in table (2).

The compost and 30 unit $\mathrm{P}_{2} \mathrm{O}_{5}$ /fed were mixed with the soil surface $\left(0-15 \mathrm{~cm}\right.$ layer) 15 days before cultivation. Also, 48 unit $\mathrm{K}_{2} \mathrm{O} / \mathrm{fed}$ as $\mathrm{K}_{2} \mathrm{SO}_{4}$ was applied with drip irrigation during the season of corn agriculture.

During the growing season, the soil moisture content in different soil layers was determined to a depth of $90-\mathrm{cm}$ at $30-\mathrm{cm}$ intervals. Soil moisture content was measured in the morning before irrigation.

Representative surface $(0-30,30-60$ and $60-90 \mathrm{~cm})$ soil samples were collected from the treated plots at flowering stage and after corn harvesting. Inorganic $\mathrm{N}$ was extracted with a 10:1 ratio of $2 \mathrm{M} \mathrm{KCl}$ to airdry soil. The extract was filtered and $\mathrm{NO}_{3}-\mathrm{N}$ was determined by steam distillation with $\mathrm{MgO}$ and Devarda alloy according to the procedure described by Keeney and Nelson (1982).

Representative leaves samples were collected at flowering stage (70 days for corn). These samples were analyzed for $\mathrm{N}$ content. Crop yield was determined for each plot at the end of the growing season. In each plot, the plants in 1.0-m length from each central row were cut by hand and the dry matter weights of the grains determined after $72 \mathrm{~h}$ of drying at $60^{\circ} \mathrm{C}$.

Physical and chemical properties of soil as well as plant residues compost were determined according to the standard methods (Black, 1982). The dried leaves and grains of plant samples were digested in concentrated $\mathrm{H}_{2} \mathrm{SO}_{4}$ and $\mathrm{H}_{2} \mathrm{O}_{2}$ at $400 \mathrm{C}^{\circ}$ and $\mathrm{N}$ was determined in the digested materials.

The PE venturi tube device ( 1 inch diam and $9 \mathrm{~mm}$ throat diam.) was used for injection fertilizer in irrigation system. The maximum injection rates (under venture level $0.5 \mathrm{~m}$ ) of the venturi is $462 \mathrm{lph}$ (at pressure differential 100\%). Figure (2) shows that calibration of the venturi (suction rate and pressure gradient). Table 3 presents suction rate of venture, inlet pressure and injection flow rate. 
Table 1: Reference values for crop coefficient (Doorenbos et al., 1977) and Reference climatologic data at Sheben El-Knater site (Agricultural Climatologic Profiles, 2004-2006)for maize crop at different stages of growth.

\begin{tabular}{|c|c|c|c|c|c|c|c|c|}
\hline Stage & Growth stage & Month & $\begin{array}{c}\text { Crop } \\
\text { coeff. }\left(\mathbf{k}_{\mathbf{c}}\right)\end{array}$ & $\begin{array}{c}\text { Tmax } \\
\left({ }^{0} \mathrm{c}\right)\end{array}$ & $\begin{array}{c}\text { Tmin } \\
\left({ }^{0} \mathrm{c}\right)\end{array}$ & $\begin{array}{c}\text { RHmax } \\
(\%)\end{array}$ & $\begin{array}{c}\text { RHmin } \\
(\%)\end{array}$ & $\begin{array}{c}\mathrm{ET}_{0} \\
(\mathrm{~mm} / \text { day })\end{array}$ \\
\hline $\mathbf{1}$ & $\begin{array}{c}\text { Establishment } \\
\text { (initial) }\end{array}$ & May & 0.40 & 33.80 & 17.76 & 77.31 & 25.87 & 7.70 \\
\hline $\mathbf{2}$ & $\begin{array}{c}\text { Vegetative } \\
\text { (development) }\end{array}$ & $\begin{array}{c}\text { June } \\
\text { July(1 } \\
\text { st }\end{array}$ & 0.75 & 35.06 & 20.16 & 82.97 & 33.01 & 7.04 \\
\hline $\mathbf{3}$ & $\begin{array}{c}\text { Flowering } \\
\text { (mid-season) }\end{array}$ & $\begin{array}{c}\text { July(2 } \\
2 \mathrm{wks})\end{array}$ & 1.15 & 34.96 & 22.14 & 85.41 & 32.93 & 7.47 \\
\hline $\mathbf{4}$ & $\begin{array}{c}\text { Yield formation } \\
\text { (late) }\end{array}$ & August & 0.85 & 34.90 & 22.09 & 86.80 & 37.28 & 6.34 \\
\hline
\end{tabular}

$\mathrm{T}_{\max }=$ maximum temperature $\left({ }^{0} \mathrm{c}\right) ; \mathrm{T}_{\min }=$ minimum temperature $\left({ }^{0} \mathrm{c}\right) ; \mathrm{RH}_{\max }=$ maximum relative humidity (\%); $\mathrm{RH}_{\min }=$ minimum relative humidity (\%).

Table 2. Some characteristics of the applied compost.

\begin{tabular}{ll}
\hline Characteristics & Compost \\
\hline Bulk density, g/cm ${ }^{3}$ & 0.33 \\
Moisture content, \% & 25.7 \\
EC (1:10), dS/m & 1.17 \\
$\mathrm{pH}(1: 10)$ & 7.18 \\
Organic matter, \% & 65.0 \\
Organic Carbon,\% & 37.7 \\
Total N, \% & 1.96 \\
Total P, \% & 1.69 \\
Total K, \% & 0.64 \\
Ash, \% & 35.0 \\
Chemically available, mg.kg & \\
$\mathrm{N}$ & \\
$\mathrm{P}$ & 986 \\
$\mathrm{~K}$ & 474 \\
$\mathrm{C} / \mathrm{N}$ ratio & 465 \\
\hline
\end{tabular}


Table 3: Suction rate with Throat velocity and injection flow rate under different inlet pressure.

\begin{tabular}{|c|c|c|c|}
\hline $\begin{array}{c}\text { Inlet pressure, } \\
\text { bar }\end{array}$ & $\mathbf{Q}_{\text {inj, }} \mathbf{~ m}^{\mathbf{3} / \mathbf{h}}$ & $\begin{array}{c}\text { Throat velocity, } \\
\mathbf{~} \mathbf{s} \mathbf{s}\end{array}$ & $\mathbf{Q}_{\text {asp }}, \mathbf{~} / \mathbf{h}$ \\
\hline 0.5 & 2.8 & 12.1 & 265 \\
\hline 0.75 & 3.2 & 13.9 & 333 \\
\hline 1 & 3.5 & 15.2 & 402 \\
\hline 1.5 & 4 & 17.4 & 430 \\
\hline 2 & 4.5 & 19.5 & 462 \\
\hline
\end{tabular}

Crop evapotranspiration $\left(\mathrm{ET}_{\mathrm{c}}\right)$ was calculated according to (Doorenbos et al., 1977).

$$
E T_{c}=E T_{o} \times K_{c}
$$

Where:

$$
\begin{aligned}
\mathrm{ET}_{\mathrm{c}} & =\text { crop evapotranspiration }(\mathrm{mm} / \text { day }), \\
\mathrm{ET}_{\mathrm{o}} & =\text { reference evapotranspiration }(\mathrm{mm} / \text { day }) \text { and } \\
\mathrm{K}_{\mathrm{c}} & =\text { crop coefficient. }
\end{aligned}
$$

Estimating of water requirements from the following equation:

$$
W R=E T_{\text {crop }} * I *(1+L R) * 4.2 .
$$

Where:

$\mathrm{W} \cdot \mathrm{R}=$ Water requirement, $\mathrm{m} 3 / \mathrm{fed}$,

L.R $=$ Leaching requirement $(20 \%)$, and

$\mathrm{I}=$ irrigation interval (allowable intervals between two irrigations), (day).

Nitrogen use efficiency (NUE) was calculated according to the following equation:

$$
N U E=\frac{\text { Total yield }(\mathrm{kg} / \mathrm{fed})}{\text { Total applied nitrogen }(\mathrm{kg} / \mathrm{fed})}--------(3)
$$



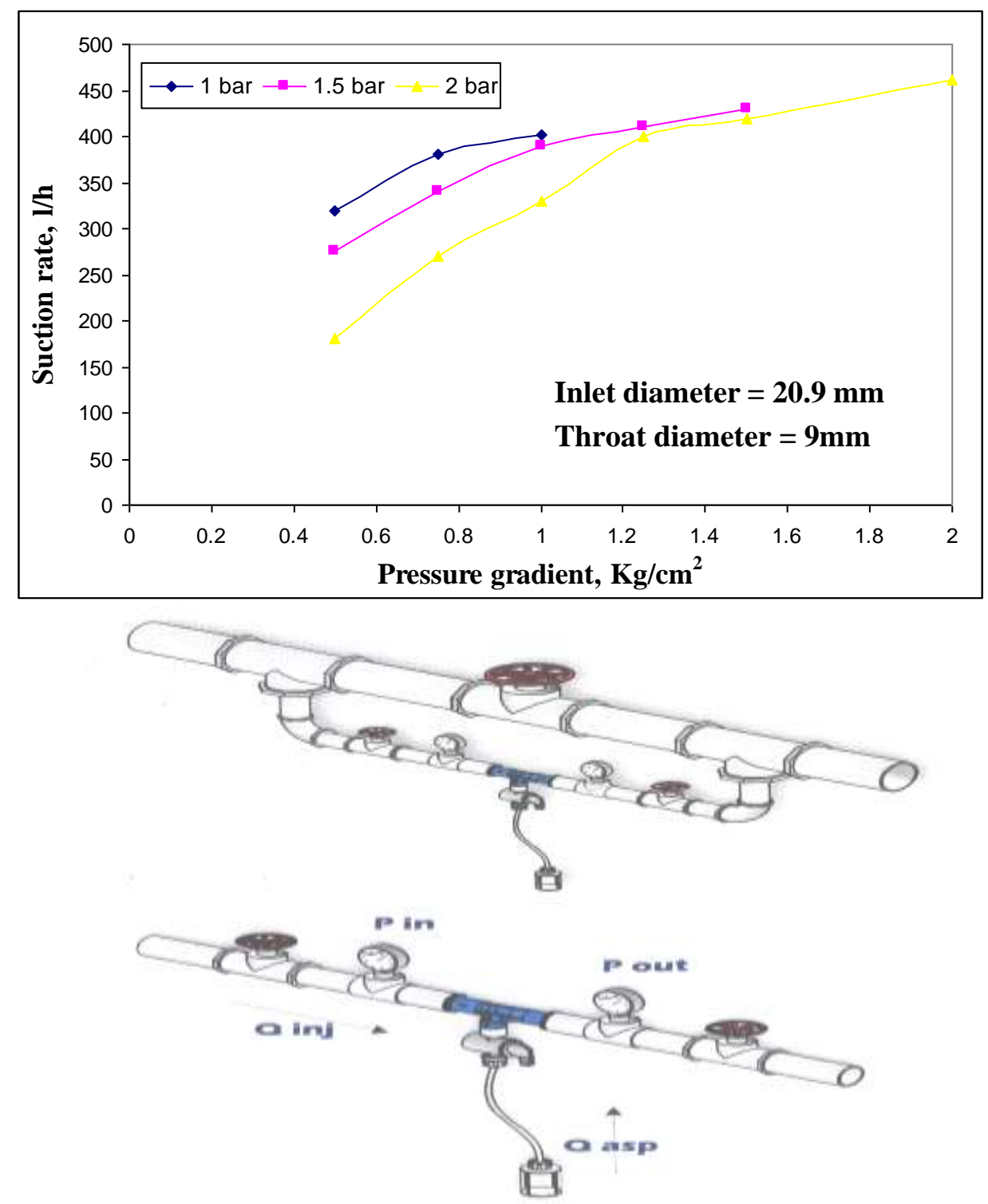

$P$ in $=\quad$ Inlet pressure, bar

$P$ out $=\quad$ Outlet pressure, bar

$Q$ inj = Injection flow rate, $\mathrm{m}^{3} / \mathrm{h}$

$\mathbf{Q}$ asp = $\quad$ Flow suction, $1 / \mathbf{h}$

Fig. 2. The relation between suction rate of the venturi and different pressure gradients and assembly venturi on the injection unit. 


\section{RESULTS AND DISCUSSION}

\section{Soil moisture content distribution with soil depth.}

The results presented in figure ( $3 \mathrm{a}$ and $3 \mathrm{~b}$ ) indicate that the soil moisture content distributions in soil layers was affected by irrigation intervals. The overall trend was that the higher moisture content found in the upper 60 $\mathrm{cm}$ layer for long time than the deepest layer $(60-90 \mathrm{~cm})$ especially with daily irrigation treatment. There was no moisture content change in the deeper soil. In the end of the season (Fig. 3b) show that the application of three days intervals increased water content in the upper layer in the first season. Gradually, soil moisture content increased with the soil depth increasing in the end of season with application of three days intervals. Whereas, application of two days intervals was increasing moisture content in the upper layer in the first season and gradually increased to 60 $\mathrm{cm}$ soil depth in the end of season. While, application of daily irrigation, the moisture content increased at depth $30 \mathrm{~cm}$, and remained practically constant below that depth through the season. Phene et al., (1991) found that in drip irrigation, root length density, and water uptake distributions with depth are related to the shape of the specific wetted volume generated by the position of the emitter and the irrigation frequency. By extension, one can assume that they will be also related to the emitter discharge as it also determines the shape of the wetted volume. In fact, visual observations on plants from the experimental plots indicated that the root system developed under the daily and two days intervals was shallower and denser than under the three days intervals. This may be led to increase higher density of root hairs and saving adequate nutrients for plant growth. 

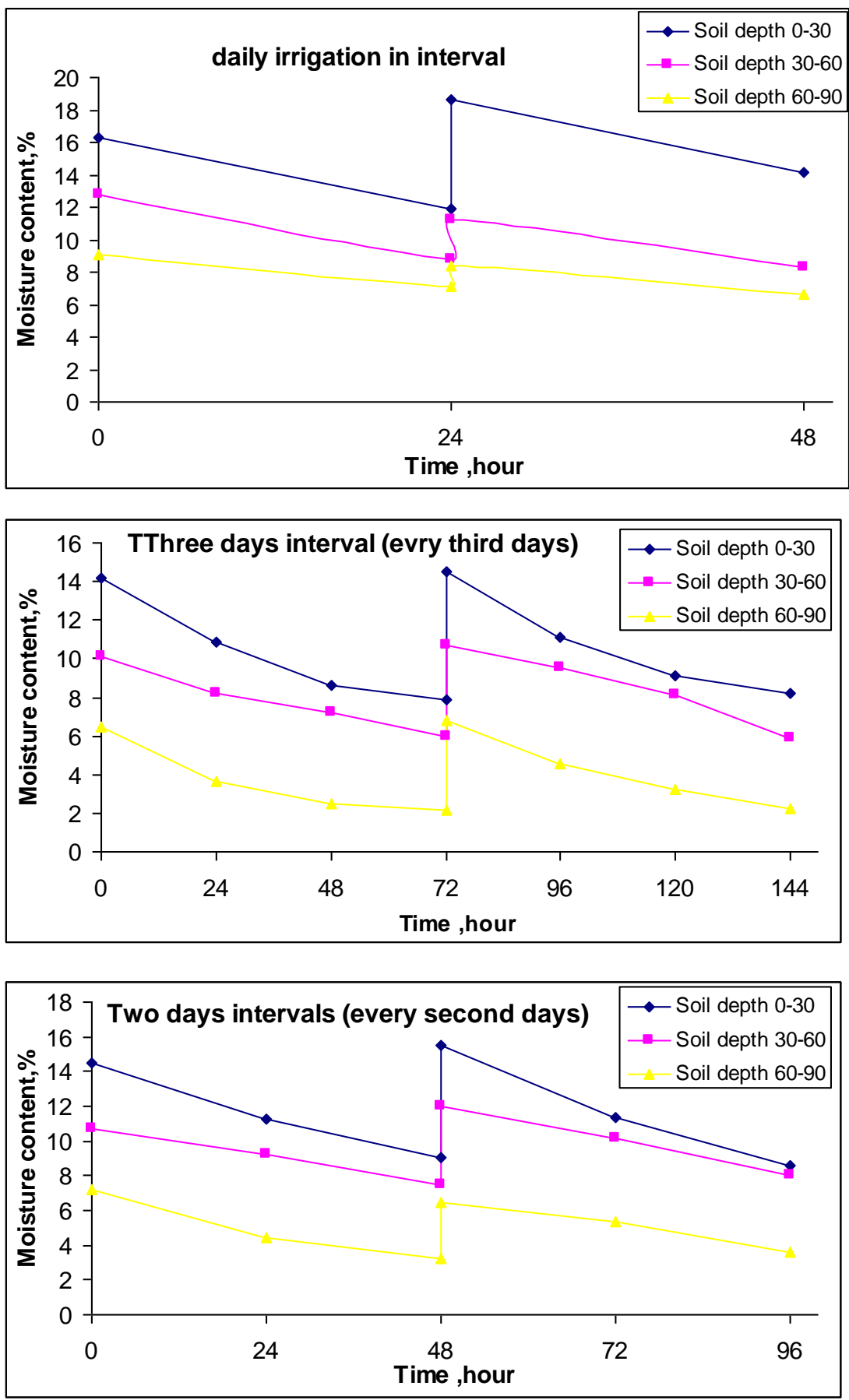

Fig. 3a: Relative moisture content distribution with depth for different treatments at the end of irrigation intervals. 

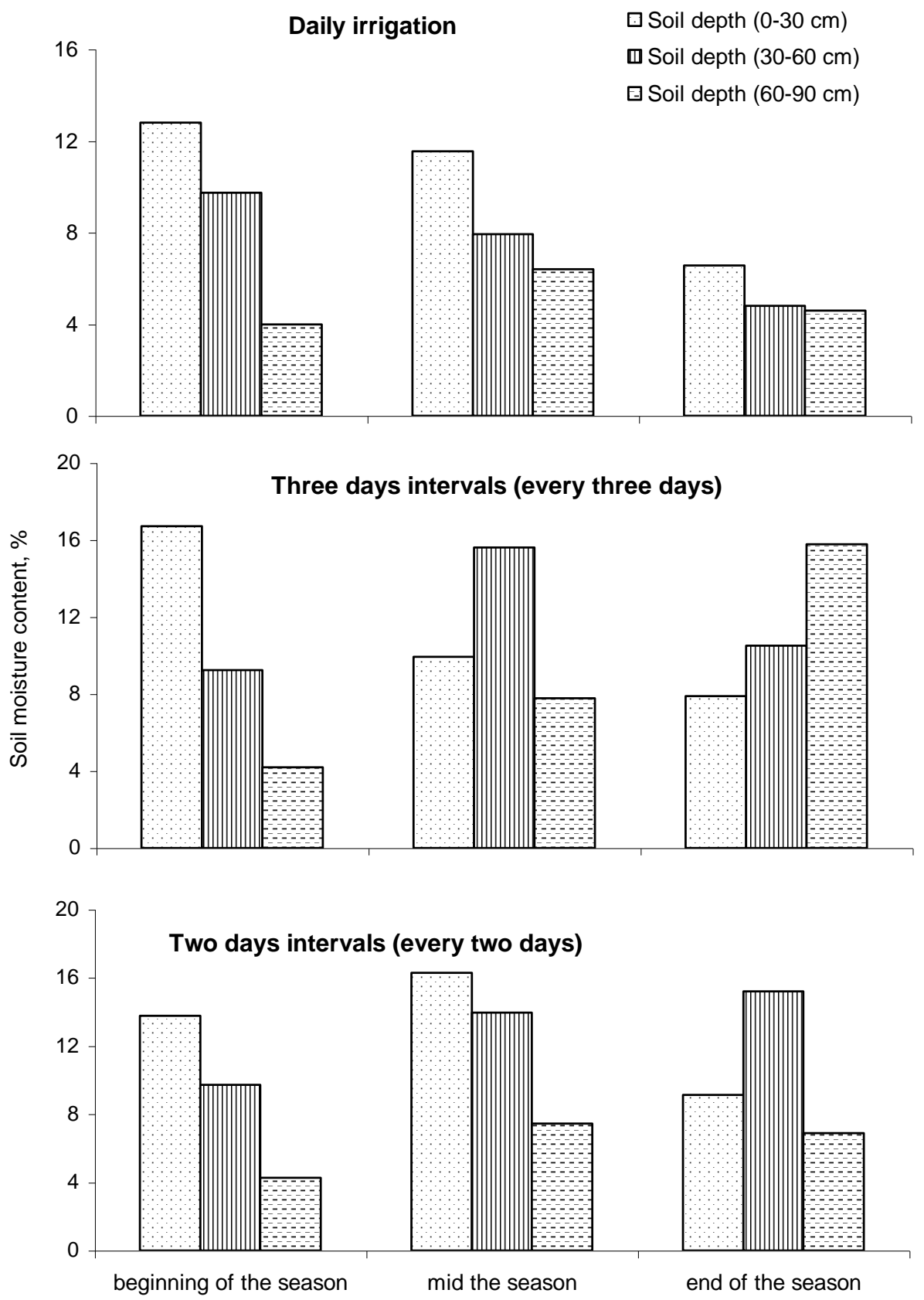

Fig. 3b. Relative moisture content distribution for different irrigation intervals in the different soil layers. 


\section{Effect of nitrogen application rate and irrigation scheduling on distribution of available soil nitrogen.}

Concerning the chemically available nitrogen through successive layers of the soil profile data in table (4) show in general decreased markedly with decreasing applied N. High amounts of nitrogen were existing in the upper layer $(0-30 \mathrm{~cm})$ of the soil and it decreased gradually with the soil depth up to (at $60-90 \mathrm{~cm}$ ) layer. The considerable amount of nitrogen remains can resist at $0-60-\mathrm{cm}$ depth. Application of inorganic nitrogen combined with compost decreasing nitrogen movement. For example, the levels of available nitrogen, at the $90-\mathrm{cm}$ depth decreased from 200.6 to 45.1, from 200.6 to 25.3 , from 172.5 , to 14.1 and from 148.4 to $7.9 \mathrm{mg}$ $\mathrm{Kg}^{-1}$ soil, with application of $100 \mathrm{Kg} \mathrm{N} / \mathrm{fed}$, (80 kg N/fed + compost), (70 $\mathrm{kg} \mathrm{N} /$ fed +compost) and (60 kg N /fed +compost) at flowering stage, respectively. Surprisingly, the total cumulative amounts of nitrogen from 0-60-cm depth were sufficient level with different treatments. The available nitrogen was 290, 283, 243 and $202 \mathrm{mg} \cdot \mathrm{Kg}^{-1}$ soil with application of $100 \mathrm{~kg} \mathrm{~N} / \mathrm{fed},(80 \mathrm{~kg} \mathrm{~N} / \mathrm{fed}+$ compost), (70 kg N /fed +compost) and (60 kg N/fed +compost) at flowering stage, respectively. This is expected since compost is reach with nitrogen and consequently increased available nitrogen in soil (table, 1). Moreover, the amount of available nitrogen in the soil at the end of the growing season was at a sufficient level in all treatments.

Chemically available $\mathrm{N}$ distributions in the soil layers as affected by irrigation scheduling are shown in table (4). The differences between nitrogen content values in the upper layer were markedly low with different treatments. Whereas, the $\mathrm{N}$ concentration were lower in the deepest layer of the soil irrigated daily compared to other treatments. Chemically available $\mathrm{N}$ levels in the soil were increasing and moving downward when soil irrigated two intervals. The increases in chemically available $\mathrm{N}$ in the subsurface layers $(30-60 \mathrm{~cm})$ of the soil irrigated two days intervals and three days intervals were 31.6 and $42.6 \%$ than that of daily irrigated soil. This may be due to when the hydraulic loading increases as decreasing irrigation intervals, the pushing down effect is faster along with higher dilution effect. The $\mathrm{N}$ concentration in the subsurface layer decreased with increasing scheduling of irrigation. This indicated greatest efficacy with daily irrigation in regard to reduce soil $\mathrm{N}$ loss and higher availability to plants. 
Table 4. Chemically available $N$ in the studied soils as affected by rate of fertilizer application and irrigation scheduling.

\begin{tabular}{|c|c|c|c|c|c|c|c|c|c|c|c|}
\hline \multirow{5}{*}{$\begin{array}{l}\text { Soil } \\
\text { depth } \\
(\mathrm{cm})\end{array}$} & \multicolumn{4}{|c|}{ Two days intervals } & \multicolumn{3}{|c|}{ Three days intervals } & \multicolumn{4}{|c|}{ Daily irrigation } \\
\hline & \multicolumn{11}{|c|}{ Rate of nitrogen fertilizer kg.fed ${ }^{-1}$. } \\
\hline & $100 \mathrm{~N}$ & $80 \mathrm{~N}$ & $70 \mathrm{~N}$ & $60 N$ & $100 \mathrm{~N} 80 \mathrm{~N}$ & $70 \mathrm{~N}$ & $60 N$ & $100 \mathrm{~N}$ & $80 \mathrm{~N}$ & $70 \mathrm{~N}$ & $60 \mathrm{~N}$ \\
\hline & \multicolumn{11}{|c|}{ Chemically available $\mathrm{N} \mathrm{mg} \cdot \mathrm{Kg}^{-1}$ soil } \\
\hline & \multicolumn{11}{|c|}{ At flowering stage } \\
\hline $0-30$ & 177.6 & 163.7 & 157.4 & 121.1 & 194.8200 .6 & 172.5 & 148.4 & 223.8 & 206.3 & 198.3 & 152.6 \\
\hline $30-60$ & 88.0 & 81.8 & 75.7 & 73.6 & 82.0 & 70.6 & 53.6 & 66.9 & 62.2 & 57.5 & 55.9 \\
\hline \multirow[t]{2}{*}{$60-90$} & 52.3 & 37.4 & 26.0 & 27.5 & 45.1 & 14.1 & 7.9 & 30.3 & 21.7 & 15.1 & 16.0 \\
\hline & \multicolumn{11}{|c|}{ At harvesting stage } \\
\hline $0-30$ & 157.2 & 102.1 & 83.7 & 66.8 & 126.6141 .8 & 116.3 & 107.0 & 114.9 & 128.6 & 105.5 & 84.1 \\
\hline $30-60$ & 91.2 & 88.0 & 63.4 & 45.6 & 107.871 .6 & 51.5 & 37.1 & 103.7 & 58.1 & 41.8 & 30.1 \\
\hline $60-90$ & 63.0 & 48.4 & 39.8 & 21.1 & 47.4 & 15.7 & 11.3 & 32.8 & 25.1 & 20.7 & 11.0 \\
\hline
\end{tabular}

\section{Effect of nitrogen application rate and irrigation scheduling on nitrogen content in corn plants.}

With regard to the effect of rate of inorganic nitrogen application and irrigation scheduling on the nitrogen content in corn plants, figure (4) reveal that application of $80 \mathrm{~kg} \mathrm{~N} /$ fed combined with compost increased markedly nitrogen content of corn plants compared with other treatments with respect of irrigation scheduling. The nitrogen content was decreased by $1.57 \%$ when the inorganic fertilizer was increased from 80 to 100 $\mathrm{kg} / \mathrm{fed}$ inorganic nitrogen fertilizer, while it was decreased by 3.03 and $6.86 \%$ when reducing the amount of inorganic fertilizer from 80 to 70 and $60 \mathrm{~kg} / \mathrm{fed}$ nitrogen, respectively.

Figure (4) show that irrigation scheduling into two days intervals or daily irrigation led to increase of nitrogen content in corn plants compared to three days intervals. Irrespective of nitrogen dose the maximum nitrogen content in corn plants was obtained with daily irrigation. The obtained values were 2.83, 2.82 and $2.87 \mathrm{~N} \%$ with two days intervals, three days intervals and daily irrigation, respectively. 


\section{Effect of nitrogen application rate and irrigation scheduling on corn grain yield.}

Data obtained for grains yield of corn are illustrated in figure (5). Applying of $80 \mathrm{~kg} \mathrm{~N} / \mathrm{fed}$ combined with compost produced relatively higher increase in grain yield than those with other treatments for example the yields were, 3.63, 3.74, 3.35 and 2.89 ton grain/fed under treatments of $100 \mathrm{~kg} \mathrm{~N} / \mathrm{fed}, 80 \mathrm{~kg} \mathrm{~N} /$ fed combined with compost, $70 \mathrm{~kg}$ $\mathrm{N} /$ fed combined with compost and $60 \mathrm{~kg} \mathrm{~N} /$ fed combined with compost, respectively. Increasing grain yield due to application of $80 \mathrm{Kg}$ of inorganic nitrogen fertilizer combined with compost over the control may be due to the effect of compost in improving the physical and chemical properties of the soil. As well as, organic manures plays a direct role in plant growth as a source of all necessary macro and micronutrients in available forms during mineralization, (Abou El-Magd et al., 2006). Chung et al., (2000) shown that application of organic manures with an adequate amount of chemical $\mathrm{N}$ fertilizer gave higher dry matter yield of maize.

Effect of irrigation scheduling on the corn grains yield are presented in figure (5). It is clear that increasing intervals of irrigation per week had markedly increased the corn grains yield. It is evident that irrigation schedule had a significant increase in grains yield regardless of nitrogen treatment. The obtained values were 3.74, 3.72 and 3.69 ton /fed with daily, two days intervals and three days intervals, respectively. This may be due to increasing availability nutrients with increasing irrigation intervals as mentioned discussed above. 


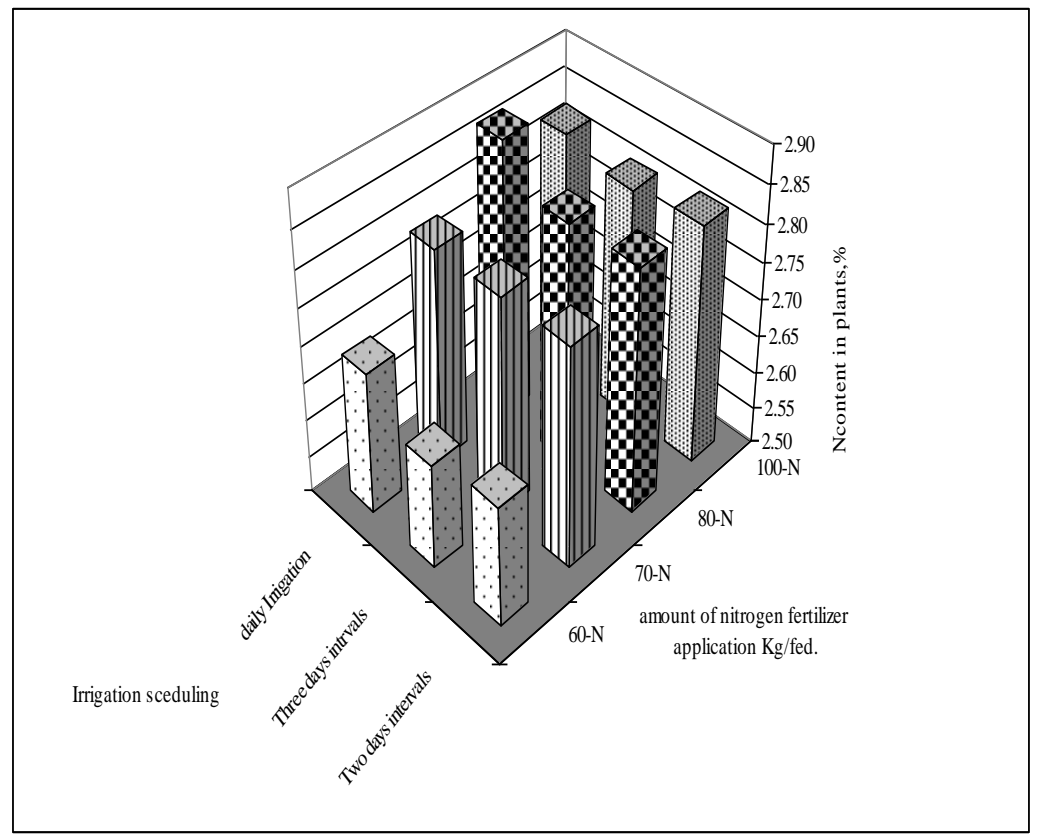

Fig. 4. The effect of fertilizer rate and irrigation scheduling on nitrogen content in

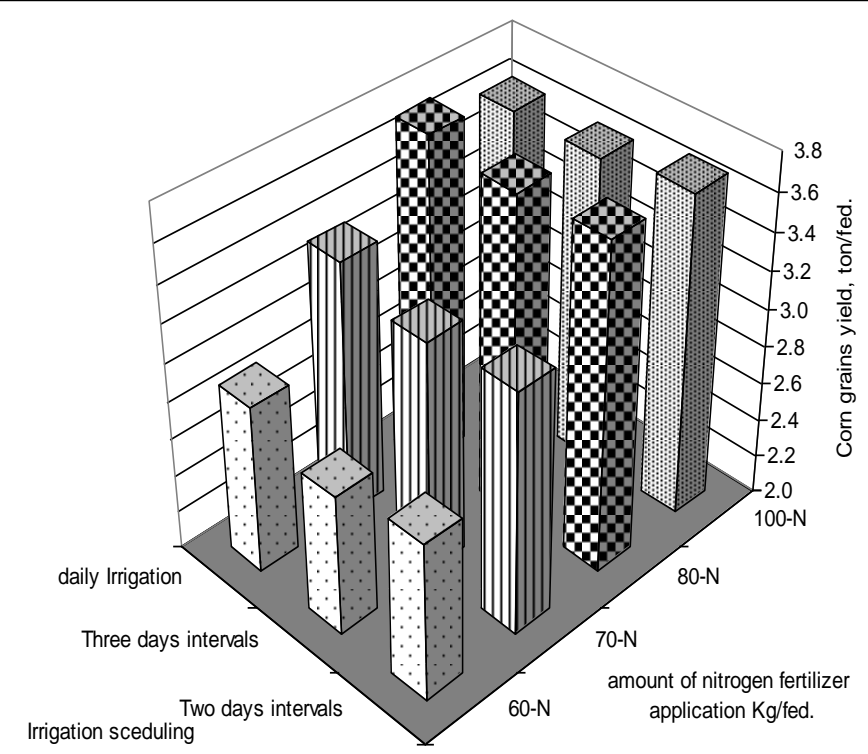

Fig. 5. The effect of fertilizer rate and irrigation scheduling on grain corn yield.

Misr J. Ag. Eng., July 2009 
Figure (6) show the relation between total amount of the grain yield and total amount of inorganic nitrogen fertilizer to estimate maximum grains yield. The relation can be formulated in the following equations:

- Under daily irrigation in interval

$\mathrm{y}=-0.0011 \mathrm{x}^{2}+0.1988 \mathrm{x}-5.012$

- Under four times irrigation in interval

$y=-0.001 x^{2}+0.1889 x-4.784$

- Under three times irrigation in interval

$y=-0.0012 x^{2}+0.2091 x-5.642$

where:

$\mathrm{y}=$ grain yield (ton/fed)

$\mathrm{x}=$ amount of inorganic nitrogen fertilizer $(\mathrm{kg})(6 \mathrm{o} \leq \mathrm{x} \geq 100)$

The relationships indicate that the corn grains yield increased by increasing the seasonal applied nitrogen up to $80 \mathrm{~kg} / \mathrm{fed}$ of the fertilizer, and then it decreased thereafter by increasing the nitrogen till $80 \mathrm{~kg} / \mathrm{fed}$ under different intervals. The grains yield was reduced by 10.4, 12 and $12.7 \%$ for corn crop under daily, two days intervals and three days interval, respectively when the fertilizer was reduced from $80 \mathrm{~kg} / \mathrm{fed}$ to $7 \mathrm{o}$ $\mathrm{kg} / \mathrm{fed}$ nitrogen, while it was reduced by $22.7,23.9$ and $25.7 \%$ when reducing the fertilizer from $80 \mathrm{~kg} / \mathrm{fed}$ to $60 \mathrm{~kg} / \mathrm{fed}$ nitrogen.

To obtain the maximum yield, the first derivative of the Nitrogen yield function equations are set equal zero and solving it. The results are presented in table (5) show that the amounts of fertilizer applied for corn under daily ,two days intervals and three days interval were, respectively, 90.36, 94.5 and $87.23 \mathrm{~kg} / \mathrm{fed}$ which produced the maximum yield of $3.97,4.13$ and 3.47 ton/fed. The results indicate that increasing intervals irrigation decreased amount of inorganic nitrogen applied and maintained the plant in conditions as well as those of the daily and two days intervals, (Fig. 3 and 4). This can be attributed to the increase in plant growth when scheduling irrigation water during growing season which in turn contributed more nutrient efficiency as well as plants more healthy as it was effect on the reproductive organs. Phene et al., (1991) mentioned that high-frequency drip irrigation has also been found to increase potato yield. 


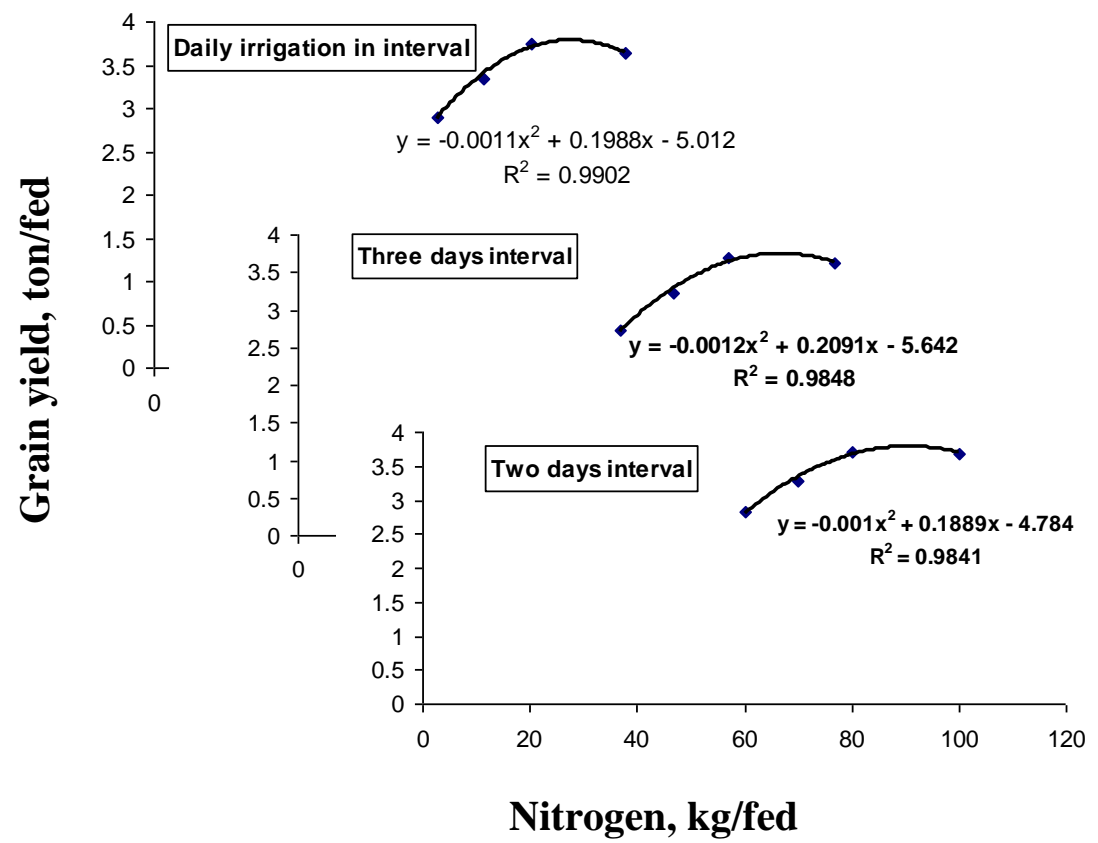

Fig. 6. The relationship between maize grain yield and seasonal applied of nitrogen fertilizer under different irrigation intervals.

Table 5 . The maximum grain yield and amount of inorganic nitrogen fertilizer applied for corn crop under different irrigation intervals.

\begin{tabular}{|c|c|c|}
\hline irrigation interval & $\begin{array}{c}\text { Max. yield } \\
\text { (ton/ fed) }\end{array}$ & $\begin{array}{c}\text { Nitrogen applied } \\
\text { (Kg/fed) }\end{array}$ \\
\hline Daily & 3.97 & 90.36 \\
Two days & 4.13 & 94.5 \\
Three Days & 3.47 & 87.13 \\
\hline
\end{tabular}




\section{CONCLUSION}

The objectives of this study were to the effect of application of compost with inorganic fertilizer and scheduling drip irrigation on distribution of nitrogen and moisture content in soil profile and dry grain yields of corn. Results showed that the irrigation intervals affected on the moisture content distributions in soil profile. The overall trend was that the upper $60 \mathrm{~cm}$ layer was more moisture content for long time than the deepest layer $(60-90 \mathrm{~cm})$ especially with daily irrigation treatment. The main noticeable differences between the treatments were that the upper soil layer dried less in the daily irrigation treatment and the soil below the root zone was contains moisture with daily and two days intervals treatments. The application of inorganic nitrogen combined with compost and scheduling drip irrigation daily intervals decreasing nitrogen movement and improved plant growth. Irrespective of nitrogen dose the maximum nitrogen content in corn plants was obtained with daily irrigation. The obtained values were 2.82, 2.83 and $2.87 \mathrm{~N} \%$ with two days intervals, three days intervals and daily irrigation, respectively. Increasing grain yield due to application of $80 \mathrm{~kg}$ of inorganic nitrogen fertilizer combined with compost over the control. Irrigation schedule had a significant increase in grains yield regardless of nitrogen treatment. The obtained values were 3.74, 3.72 and 3.69 ton /fed with daily, two days intervals and three days intervals, respectively. The results indicate that increasing intervals irrigation decreased amount of inorganic nitrogen applied and maintained the plant in conditions as well as those of the daily and three days intervals. 


\section{REFERENCES}

Abou El-Magd; M.A., M. El-Bassiony and Z.F. Fawzy (2006). Effect of organic manure with or without chemical fertilizers on growth, yield and quality of some varieties of Broccoli plants. J. Appl. Sci. Res., 2 (10):791-798.

Agricultural Climatologic Profiles (2004-2006). Central Laboratory for Agricultural Climate - Agriculture Research Center, Ministry of Agriculture and Land Reclamation.

Albus, W.L. and R.E. Knighton (1998). Water quality in a sand plain after conversion from dryland to irrigation: Tillage and cropping systems compared. Soil Tillage Res. 48:195-205.

Belay, A.; A. S. Classens; F. C. Wehner and J.M. De Beer (2001). Influence of residual manure on selected nutrient elements and microbial composition of soil under long-term crop rotation. South Afr. J. Plant and Soil, 18: 1-6.

Black, C.A.(1982). Methods of soil analysis. Part. (2) Am. Soc. of Agrn.,INC., Publisher Madison Wisconsin, USA.

Bresler, E., B.L. McNeal, and D.L. Carter (1982). Saline and Sodic soils. Advanced Series in Agricultural Sciences 10. Springer-Verlag. Berlin.

Chung, R.S, C.H.Wang, C. W. Wang and Y.P Wang (2000). Influence of organic matter and inorganic fertilizer on the growth and nitrogen accumulation of corn plants. J. Plant Nutr., 23: (3):297311.

Coelho, E.F., and D. Or (1996). A parametric model for two-dimensional water uptake by corn roots under drip irrigation. Soil Sci. Soc. Am. J. 60:1039-1049.

Coelho, E.F. and D. Or. (1999). Root distribution and water uptake patterns of corn under surface and subsurface drip irrigation. Plant Soil 206:123-136.

Darusman, A.H.; L.R. Khan; W. E. Stone and F.R. Lamm (1997). Water flux below the root zone vs. irrigation amount in drip-irrigated corn. Agron. J. 89:375-379. 
Doorenbos, J. and W. O. Pruitt (1977). Guidelines for predicting crop water requirements, FAO Irrigation and Drainage, Paper 24. Rome, Italy: 156pp.

Doran, J.W. (1980). Soil microbial and biochemical changes associated with reduced tillage. Soil Sci. Soc. Am. J. 44:765-771.

Elbordiny, M. M. (1996). Behaviour and loss of nitrogen in relation to the environment. M. Sc. Thesis, Fac. of Agric., Ain Shams Univ., Egypt.

FAO. (1990). Fertilizer yearbook 1990. Rome.

Galloway, J.N., W. H. Schlesinger, H. Levy, A. Michaels and J. L. Schnoor (1995). Nitrogen fixation-anthropogenic enhancementenvironmental response. Glob. Biogeochem. Cycl., 9: 235-252.

Keeney, D.R. and D.W. Nelson. (1982). Nitrogen-Inorganic forms. p. 643-698. In A.L. Page et al., (ed.) Methods of soil analysis. Part (2). $2^{\text {nd }}$ ed. Agron. Monogr. 9. ASA and SSSA, Madison, WI.

Phene, C.J.; K.R. Davis; R.B. Hutchmaker; B. Bar-Yosef; D.W. Meek and J. Misaki. (1991). Effect of high frequency surface and subsurface drip irrigation on root distribution of sweet corn. Irrig. Sci. 12: 135-140.

Sanchez C.H.A . (2000). Response of lettuce to water and nitrogen on sand and the potential for leaching of nitrate-N. Hort. Science., 35(1): 73-75.

Seifritz, W.(1982). Alternative and renewable sources of energy in optimizing yields: The role of Fertilizers. In: Proc. of 12th IPI Congress, 153-163.

Sharma, A.R. and B.N. Mittra(1991). Effect of different rates of application of organic and nitrogen fertilizers in a rice-based cropping system. J. Agr. Sci., 117: 313-318.

Steele, D.D.; E.C. Stegman and R.E. Knighton (2000). Irrigation management for corn in the northern Great Plains, USA. Irrig. Sci.,19:107-114.

Türkmen, Ö.; M. A. Bozkurt ; M.Yıldız and K. M. Çimrin (2004). Effect of nitrogen and humic acid applications on the head weight, nutrient and nitrate contents in lettuce. Adv. Food Sci. 26(2): 5963. 


\section{الملخص العربيى

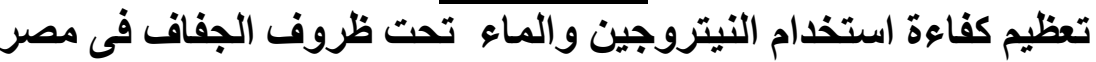

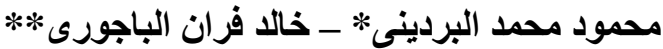

فقد النيتروجين بالغسيل من اكبر المشاكل خاصة مع المحاصيل التى تحتاج لكميات كبيرة

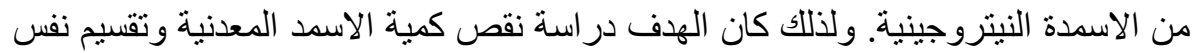

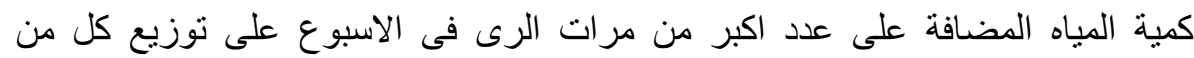

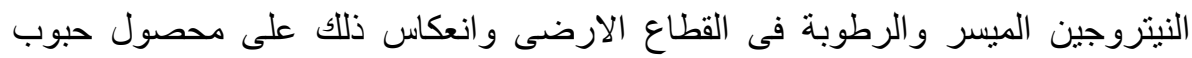

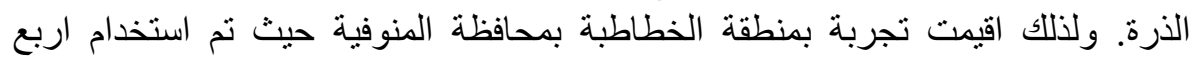

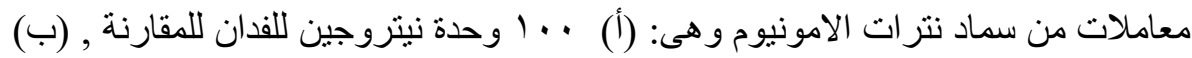

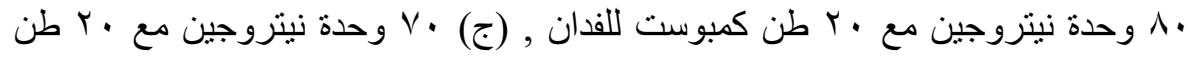

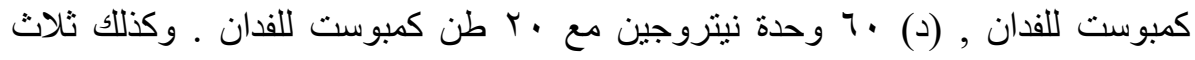

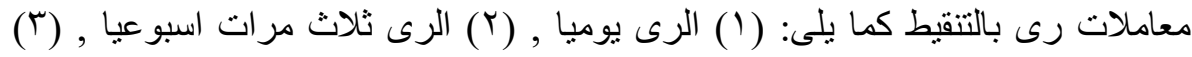

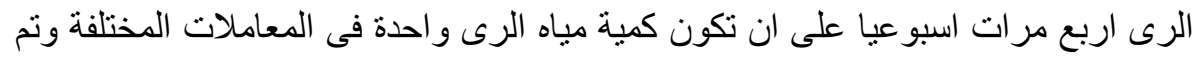

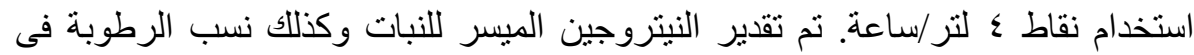

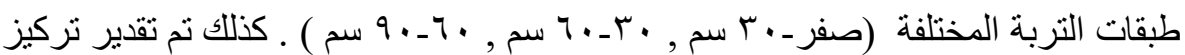

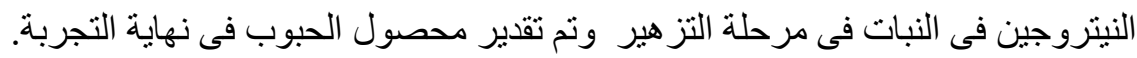
و اوضحت النتائج ما يلى: استخدام الرى يوميا ادى الى زيادة الرطوبة فئى الطبقة السطحية

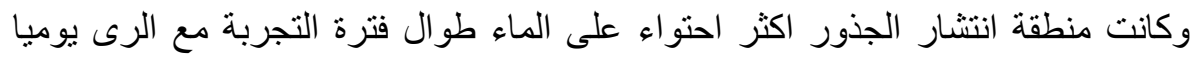

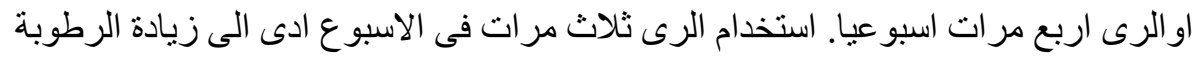

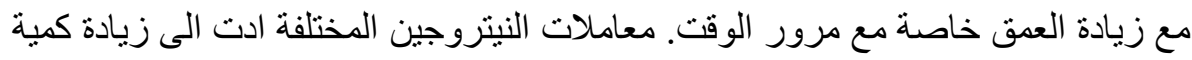
النيتروجين فى الطبقة السطحية وانخفض تركيز النيتروجين مع زيادة عمق التربة ـ ـواتضح ان كمية النيتروجين الميسرة للنبات فى الطبقة (صفر- • 7 سم ) كانت فى الحدود الكافية

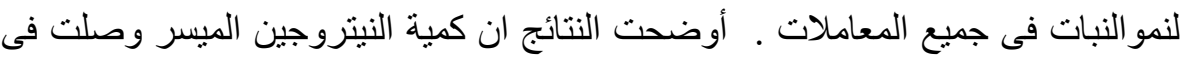

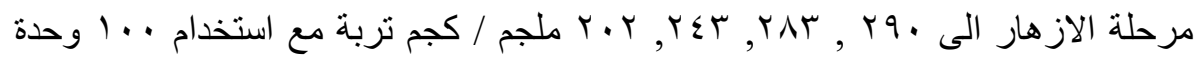

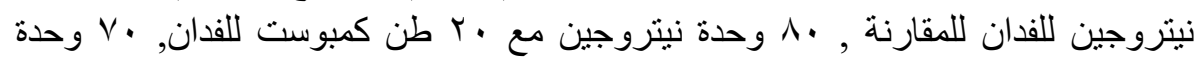

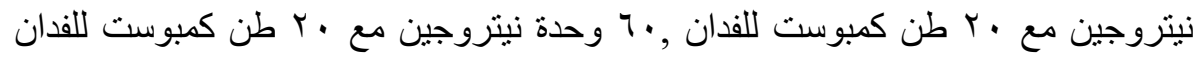

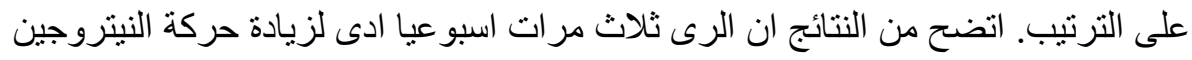

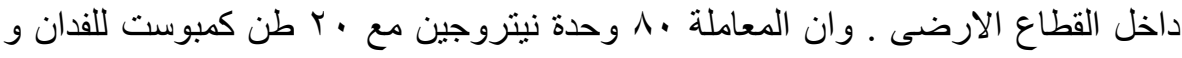

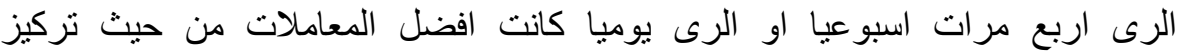
النيتروجين فى النبات وكمية محصول الحبوب وخفض كمية النيتروجين المتحركة لاسفل.

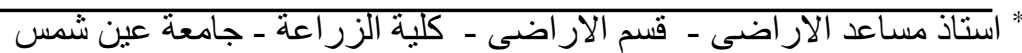

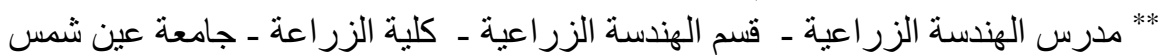

